\title{
Dry Azolla Based Feed Formulation for Fresh Water Carp
}

\author{
Sakthi Pemila Rajan ${ }^{1}$, Selvi Subramanian ${ }^{1 *}$, Muthulakshmi Chellamuthu ${ }^{1}$ \\ \{sakthipemila0897@gmail.com ${ }^{1}$,selvi.bio@psgtech.ac.in²,muthumohanraj86@gmail.com³ \\ Department of Biotechnology, PSG College of Technology, Coimbatore-641004, \\ Tamil Nadu, India ${ }^{1}$
}

\begin{abstract}
Azolla pinnata is a macro alga rich in protein, essential amino acids, vitamins and minerals. Hence it can be used in sustainable animal feed production. In this study, fish feeds were formulated using wheat flour, fish meal, groundnut oil cake combined with either $25 \%$ or $30 \%$ of dried Azolla. Fish feeding experiments were conducted with Catla fries in tanks using commercial feed (C), 25\% Azolla replaced (T1) and 30\% Azolla replaced (T2) feeds. Catla fishes grown in Azolla replaced feed formulations showed higher growth with $2 \%$ increase in their body weight compared to control feed. In addition, survival rate and nutrient contents such as carbohydrate, and protein were also found higher in fishes grown in dry Azolla based feeds than commercial feed. This study substantiates that dry Azolla can be used as a cheap nutrient supplement in fish feeds.
\end{abstract}

Keywords: Azolla pinnata, Carp, Catla catla, Feed formulation, Proximate analysis.

\section{Introduction}

Fishing is an important occupation in India due to its vast coastal area. India is the third largest fish producer and ranks second in the production of farmed fishes. The state Tamil Nadu is the fifth highest producer in the Indian scenario (World Bank 2013). Fish accounts for $20 \%$ of the animal derived protein in low income, food deficit countries. Nearly $17 \%$ of the global protein intake comes from fishes. Expansion in aquaculture may help alleviate protein malnutrition especially in poor rural areas. In order to attain sustainability in fish production it is necessary to reduce the dependability on wild fishes and to intensify fish farming (Delgado et al 2002). By 2030, aquaculture will produce two third of the global food fish (World Bank 2013). Thus, the aquaculture industry is expected to grow significantly in the near future.

Carps are the most farmed fish species in India. They provide $26.2 \%$ of the total animal meat and are considered as the fast-growing food source in Asia (Delgado et al 2002). The three major carps are Catla catla (Catla), Labeo rohita (rohu) and Cirrhinus mrigala (mrigal). Preference for growing these fishes are mainly because of the ease of culture, rapid growth, attainment of large size, compatibility, keeping quality, consumer preference and hardness which makes it easy to handle and transport. Catla is also known as the major Indian carp, which is considered as the economically most important fish of South Asia. Fish farmers like to grow Catla because it attains $1-1.2 \mathrm{~kg}$ in the first year while rohu and mrigal attain $600-$ $800 \mathrm{~g}$. Azolla is a prominent ingredient used in diets of fish because of its high protein content and excellent amino acid profile. It is an aquatic fern which can be grown in ponds, ditches 
and rice fields of warm-temperate and tropical regions throughout the world (Lumpkin and Plucknett 1980). It can be fed to livestock either in a fresh or dried form. It can be fed either directly or mixed with concentrates to livestock (Giridhar and Rajendran 2013). Soybean or fish meal can be partially substituted with Azolla (Gangadhara et al 2018). Thus, there will be reduction in the usage of high cost protein sources like fish meal and soya bean in fish feeds when Azolla is used. In this study, dry Azolla based fish feeds were formulated and evaluated in fresh water carp, Catla catla with an objective to estimate whether there is an increase in growth, and survival rate and nutrient content of fishes.

\section{Materials And Methods}

\section{Azolla cultivation and drying}

Fresh Azolla was cultivated in tubs which were filled with fertilizer, rock phosphate and cow dung slurry. Fresh Azolla was seeded in the tubs and harvested in 6-8 days when the tub was fully covered with grown Azolla (Figure 1A and 1B). Azolla harvested was shade dried, powdered and used in the feed.

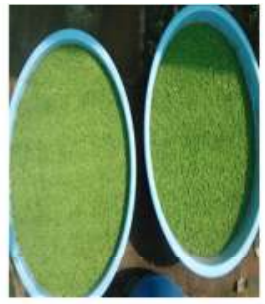

Azolla cultivated in tub

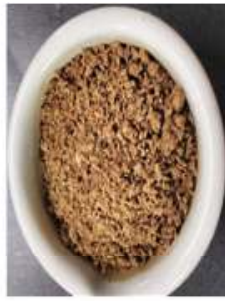

Dried Azolla
T1

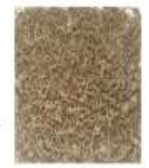

T2

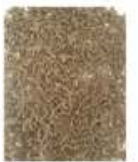

C

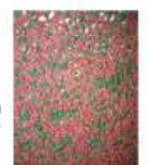

Fig 1A. Fresh Azolla cultivated in tubs within a week for feed preparation.
Fig 1B. Images of formulated fish feed for Catla catla. T1 feed, T2 feed and (C) control feed

\section{Fish feed formulation}

Along with dry Azolla, other ingredients like fish meal, wheat flour and groundnut cake were powdered and used as per the requirement of Catla feed farming studies. Feeds were prepared based on the ratio tabulated in Table1. For $100 \mathrm{~g}$ of ground feed material $140 \mathrm{ml}$ of water was used to make fine dough for extrusion. Dough was made to pellets using a kitchen extruder of pore size $2 \mathrm{~mm}$. Then, the extruded pellets were dried in oven at $80^{\circ} \mathrm{C}$ for 36 hours. The nutrient content of the feeds was estimated by proximate analysis following the protocols for carbohydrate from (McCluer 1963) and protein, lipid, ash and moisture content from "Proximate analysis of feed stuff" (2009) which followed AOAC protocol.

Table 1: Fish feed composition

\begin{tabular}{|c|c|c|c|}
\hline Ingredients & $\begin{array}{l}\text { Test feed } 1 \\
\text { (T1) (\%) }\end{array}$ & $\begin{array}{l}\text { Test feed } 2 \\
\text { (T2) (\%) }\end{array}$ & $\begin{array}{l}\text { Control feed } \\
\text { (C) }(\%)\end{array}$ \\
\hline Azolla & 25 & 30 & Nil \\
\hline Fish meal & 44 & 40 & $\checkmark$ \\
\hline Groundnut oil cake & 11 & 10 & Nil \\
\hline
\end{tabular}




\begin{tabular}{lllc}
\hline Wheat Flour & 20 & 20 & $\checkmark$ \\
Soya bean meal & Nil & Nil & $\checkmark$ \\
Corn meal & Nil & Nil & $\checkmark$ \\
Yeast & Nil & Nil & $\checkmark$ \\
\hline
\end{tabular}

Fish feeding experiments

Fish feeding experiments were carried inside a poly house in polyethylene fish tanks at PSG College of Technology, Coimbatore, India during November 2018 to April 2019. Tanks were swabbed well; three-fourth of the tank was filled with tap water and then seeded with 150 fish fries in each tank. The tanks were cleaned once a week. The fish fries were fed with $1 / 3^{\text {rd }}$ of their average body weight once a day every morning. Dry Azolla based fish feed formulations T1-25\% Azolla replaced, T2-30\% Azolla replaced and the C-control is a commercial feed.

\section{Data collection and Analyses}

Wet weight of the fry was measured using an electronic analytical balance, taking random sample $(n=15)$ from each tanks and count of live fishes was also taken with monthly intervals. Percentage increase in weight of fishes was also calculated using current weight comparison to the original weight of the fish fries. Survival rate of fishes for each feed was also calculated.

$\%$ increase in weight gain $=(($ final weight - initial weight $) /$ initial weight $) * 100$

Survival $\%=($ No. of fishes survived / No. of fishes initially introduced $) * 100$

After a growth period of five months, nutrient content in fishes such as carbohydrate, protein and fat were analysed in fish samples. Cost of feed ingredients was noted and cost analyses were done for each feed.

\section{Statistical analysis}

The statistical analysis was done using one-way ANOVA in Excel. The $\mathrm{p}$ value and $\mathrm{F}$ value were calculated to measure the significance of the results obtained.

\section{Results}

\section{Comparison of fish feeds}

Nutrient composition of dry Azolla based feed formulations (T1 and T2) and control feeds are compared in Fig. 2. The test feeds were found to have matching levels of protein and carbohydrate with the Control feed. Lipid, moisture and ash levels were found to be low in the control feed (C). The lipid contents were 4.5\% and 6\% in dry Azolla replaced Test feeds T1 and T2 respectively. Moisture content was $25 \%$ in the formulated feeds whereas it was only $10 \%$, much lower in the control feed. 


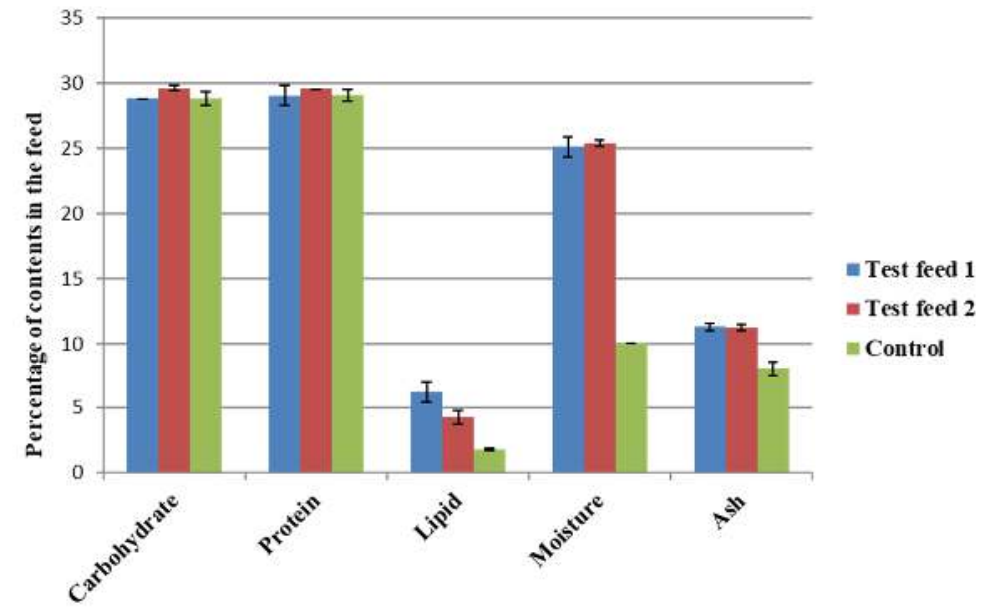

Fig 2. Graphical representation of quantitative analysis of test feeds and control feeds

\section{Survival and Growth rate}

The number of fish lings survived over a period of five months' time fed with test feeds $\mathrm{T} 1, \mathrm{~T} 2$ and control were represented in figure 3 . The mortality was higher in control feed compared to test feeds.

Growth rate of fish was measured in terms of weight gain in fishes (Fig. 4) and increase in the length of fishes (Fig.5). Overall, there was only a marginal weight gain difference of $2 \%$ $(90-92 \%)$ observed between treatments. Test feed which had 30\% replacement Azolla had the highest weight gain and control feed the lowest.

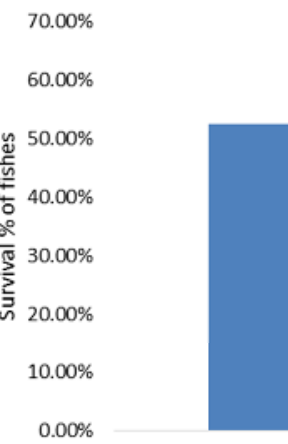

T1

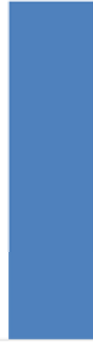

T2

Fish feed used

Fig 3. Graphical representation of survival of fishes in the growth period 


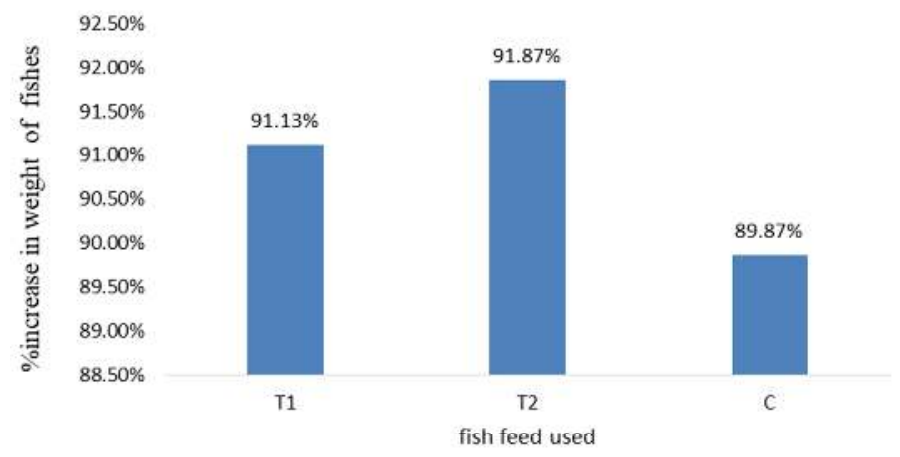

Fig 4. Graphical representation of percentage increase in weight of fish lings

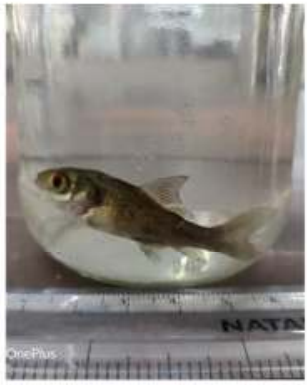

A

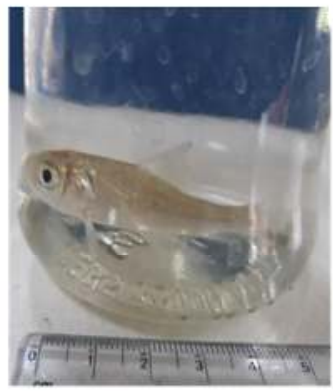

B

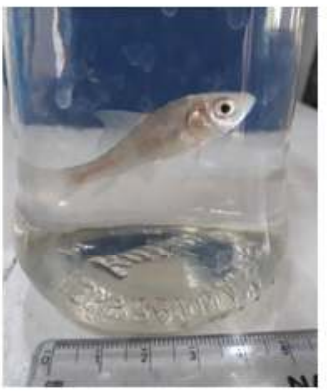

C

Fig 5. Images of fish lings grown after five months

A) Fishes fed with T1 feed B) Fishes fed with T2 feed C) Fishes fed with C1 feed.

\section{Nutrient content of fishes}

The test feeds in which the protein source is replaced with Azolla but matched to the requirement of Catla fishes were given to them along with a commercially available fish feed. The nutrient status of the five month grown fishes were analysed by measuring the carbohydrate (Fig. 6), protein and lipid (Fig. 7). The results indicate that T2 feed with 30\% Azolla replacement fed fishes had the highest carbohydrate, protein and lipid content. Fishes fed with the control feed had the lowest amount of carbohydrate and protein. The lipid content was found to be least in the fishes fed with T1feed. All the observed values of test feed and values for the fishes fed with test feed were significant $(\mathrm{P}<0.05)$ compared to the control feed and fishes. 


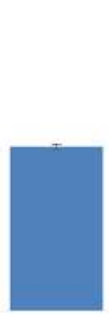

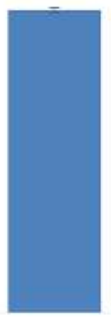

12

fish feed used

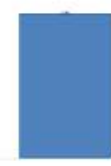

C1

Fig 6. Graphical representation of percentage of carbohydrate in the fishes fed with different feeds

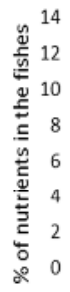
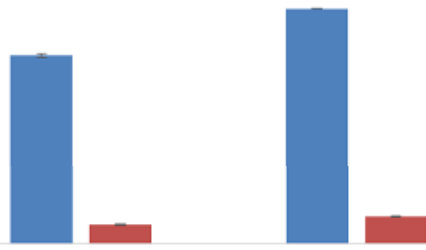

t2

fish feed used

a Protein = Lipid

Fig 7. Graphical representation of percentage of protein and lipid in the fishes fed with different feeds

\section{Cost analyses of feed}

Azolla, a cheap source of protein was replaced to a tune of 25 and $30 \%$ in fish feed formulations to reduce the cost of fish feed. A cost comparison of ingredients used in three feeds used in the study is given in table 2. Fish meal was the high cost component. The test feed T2 which had the highest amount of Azolla had the lowest cost among the three feeds. The commercial feed price is the highest.

Table 2: Estimated cost of production of feeds used (for $1 \mathrm{~kg}$ of feed)

\begin{tabular}{llll}
\hline Ingredients & T1 (in rupees) & T2 (in rupees) & C (in rupees) \\
\hline Dry Azolla powder & 25 & 30 & Nil \\
Fish meal & 396 & 360 & 504 \\
Groundnut oil cake & 4.4 & 4 & 6 \\
Wheat flour & 16 & 16 & 23.2 \\
TOTAL & 441.4 & 410 & 533.2 \\
\hline
\end{tabular}




\section{Discussion}

Dry Azolla replacement for protein in fish feeds of about $25 \%$ and $30 \%$ were evaluated in this study. Wheat flour, groundnut oil cake and fish meal along with Azolla were used to bring the required protein content. Arable land available for cultivation is reducing, hence aquatic fern that can be cultivated easily with protein accumulation of up to 176$208 \mathrm{~g} \mathrm{~kg}^{-1}$ DW (Brouwer et al 2018) is a suitable alternate protein feedstock for fish feeds. Protein content in fish feeds were matched to the requirement of Catla fish; on doing that fat and ash content were found to be higher than control feed (Fig.2). The lipid content in the formulated feed was in the range of 4.5 to $6 \%$. The results coincided with the report of (Anitha et al 2016) who reported $4.5 \%$ lipid content in their study. The ash content in test feeds was higher than control (Fig. 2) since Azolla is a fern rich in minerals and hence the ash content is expected to be higher (Roy et al 2016). The quantitative analysis of feeds coincided with the findings for Azolla formulated feeds in ICAR (2006).

Evaluation of the formulated feed with the Catla fish lings indicated that $30 \%$ Azolla showed higher survival and increased body weight. Similarly, fresh water prawn showed high growth and good feed efficiency with diets containing 17\% Azolla supplemented with or without Digestin enzyme (Goda et al 2018). In contrast, growth of carp was found to be poor when Azolla replacement was 15\% and 25\% compared to 5\% (Abdalbakee and Mohammed 2019). Similarly, complete protein supplementation with soybean has shown reduced growth compared to $65 \%$ fishmeal silage in the growth of red tilapia fishes (Moharram and Raky 2007). Azolla replacement in poultry feed up to $10 \%$ in nera brown chicks has shown weight gain whereas, a $15 \%$ replacement showed reduced feed intake and weight gain (Alalade and Iyayi 2006). This study suggests that fishes prefer Azolla better than chicks.

Better growth performance in 30\% Azolla replaced feed of fishes meant better digestion, absorption and feed conversion of nutrients to flesh. The protein content in fishes increased as the Azolla content increased (Fig. 7) in the feed suggesting a good nutrient utilization. A slight increase in lipid and carbohydrate levels (Fig. 6 and 7) were observed in fishes fed with $30 \%$ Azolla replaced feed. Similar observation, in fresh water prawn fed with 17\% Azolla replaced diet was observed by (Goda et al 2018) in lipid content. However (ElSyed 1992) have reported that fresh and dry Azolla replacement in feed is negatively correlated to body protein and lipid contents in Nile tilapia. The cost of fish meal is ten times higher than the other components. Reducing the fish meal in feed will reduce the cost. The cost of Azolla based feed is lower due to the reduction in the fish meal component. Azolla is rich in calcium, phosphorous, potassium, ferrous, copper, magnesium, and several vitamins (Gouriet al 2012). The components present in Azolla are comparable to fish meal. Azolla can be increased up to $45 \%$ in fish feed (Mosha 2018) hence further reduction in fish meal can be evaluated in future.

\section{Conclusion}

In this study, it is observed that dry Azolla can be replaced to a tune of $30 \%$ in fish feeds without causing any adverse effect on growth and survival rate of Catla fishes. In addition, improved protein and marginal increase in fat content in Catla fishes were also observed. The cost of this unconventional feed ingredient is lesser than the traditional high 
protein feed stocks. In future, dry Azolla can be used as a cheap protein source for growing fresh water carps.

\section{Acknowledgements}

Authors thank the funding agency, Department of Science and Technology, Government of India, for sponsoring the project "Rural Women Technology Park for Coimbatore District, Tamil Nadu, under which this work was carried.

\section{References}

[1] Abdalbakee \& Mohammed, H.N. (2019). Effect of using different levels of Azolla as a substitute for soy bean meal in the production performance of fish carp. Plant Archives,19(1), 573577.https:// doi.org/10.13140/RG.2.2.23568.15367

[2] Alalade, O. A., \& Iyayi, E. A. (2006). Chemical composition and the feeding value of Azolla (Azolla pinnata) meal for egg-type chicks. International Journal of Poultry Science, 5(2), 137141.http://dx.doi.org/10.3923/ijps.2006.137.141

[3] Anitha, K.C., Rajeshwari, Y.B., Prasanna, S.B., \& Shilpa Shree, J. (2016). Nutritive evaluation of Azolla as Livestock feed. Journal of Experimental Biology and Agricultural Sciences, 4(6),670674.https://doi.org/10.18006/2016.4(Issue6).670.674

[4] Ayyappan, S., Jena, J. K., Gopalakrishnan, A., \& Pandey, A. K. (2006). Handbook of fisheries and aquaculture. Indian Council for Agricultural Research.

[5] Brouwer, P., Schluepmann, H., Nierop, K. G., Elderson, J., Bijl, P. K., van der Meer, I., \& van der Werf, A. (2018). Growing Azolla to produce sustainable protein feed: the effect of differing species and $\mathrm{CO} 2$ concentrations on biomass productivity and chemical composition. Journal of the Science of Food and Agriculture, 98(12), 4759-4768.https://doi.org/10.1002/jsfa.9016

[6] Delgado, C. L., Rosegrant, M. W., Wada, N., Meijer, S., \& Ahmed, M. (2002). Fish as food: projections to 2020 under different scenarios (No. 595-2016-39966). https://doi.org/10.22004/ag.econ.16229

[7] El-Sayed, A. F. (1992). Effects of substituting fish meal with Azolla pinnata in practical diets for fingerling and adult Nile tilapia, Oreochromis niloticus (L.). Aquaculture Research, 23(2), 167173. https://doi.org/10.1111/j.1365-2109.1992.tb00607.x

[8] Gangadhar, B., Umalatha, H., Hegde, G., \&Sridhar, N. (2017). Digestibility of Dr y Matter and Nutrients from Azolla pinnata by Labeo calbasu (Hamilton, 1822) with a note on digestive enzyme activity. Fish Technology, 54:94-99. https://doi.org/10.19080/OFOAJ.2018.05.555672

[9] Giridhar, K., \& Rajendran, D. (2013). Cultivation and usage of Azolla as supplemental feed for dairy cattle. In: Value addition of feed and fodder for dairy cattle. NIANP, 32-34.

[10] Goda, A., Saad, A., Hanafy, M., Sharawy, Z., \& El-Haroun, E. (2018). Dietary effects of Azolla pinnata combined with exogenous digestive enzyme (Digestin ${ }^{\mathrm{TM}}$ ) on growth and nutrients utilization of freshwater prawn, Macrobrachium rosenbergii (de Man 1879). Journal of Oceanology and Limnology, 36(4), 1434-1441.https://doi.org/10.1007/s00343-018-7019-7

[11] Gouri, M. D., Sanganal, J. S., Gopinath, C. R., \& Kalibavi, C. M. (2012). Importance of azolla as a sustainable feed for livestock and poultry-A review. Agricultural Reviews, 33(2), 93-103.

[12] Lumpkin, T. A., \& Plucknett, D. L. (1980). Azolla: botany, physiology, and use as a green manure. Economic Botany, 34(2), 111-153.https://doi.org/10.1007/BF02858627

[13] McCluer, R. H. (1963). Methods in carbohydrate chemistry. Volume 1, analysis and preparation of sugars (Whistler, Roy L.; Wolfrom, ML; ed. s).

[14] Moharram, S. G., \& Raky, F. A. (2007). Effect of varying dietary protein sources on growth and spawning performance and gonad maturation of red tilapia reared in sea water. Pakistan Journal of Biological Sciences, 10(21), 3742-3751.https://doi.org/ 10.3923/pjbs.2007.3742.3751. 
[15] Mosha, S. S. (2018). A Review on Significance of Azolla Meal as a Protein Plant Source in Finfish Culture. Journal of Aquaculture Research and Development, 9(544), 2. https://doi.org/ 10.4172/2155-9546.1000544.

[16] Proximate analysis of feed stuff (lecture notes), Federal University of Agriculture, Abeokuta, http://unaab.edu.ng./ Retrieved on 2009/12.

[17] M. Tholkapiyan, A.Mohan, Vijayan.D.S , "A survey of recent studieson chlorophyll variation in Indian coastal waters", IOP Conf. Series: Materials Science and Engineering 993 (2020) 012041, doi:10.1088/1757-899X/993/1/012041.

[18] World Bank. 2013. Fish to 2030: prospects for fisheries and aquaculture (English). Agriculture and environmental services discussion paper; no. 3. Washington DC; World Bank Group. 